\title{
In Remembrance
}




\section{Heinrich Benedikt (1886-1981)}

Heinrich Benedikt died in Vienna on December 26, 1981, four days before his ninety-fifth birthday. He was the oldest of three historians who, born and grown to maturity in the Habsburg monarchy, imparted their knowledge of Habsburg history to the infant Second Republic, and he has been the last to leave us. Reference here is to the triad of Hugo Hantsch (1895-1972), Friedrich Engel-Janosi (1893-1978) and Benedikt, whose impact on the writing and teaching of Austrian history in the twenty-five years from the late forties to the early seventies has been considerable.

Benedikt's family was rooted in the Jewish grande bourgeoisie of nineteenth-century Vienna, with many ramifications in numerous banking families all over Europe. In his memoirs published in 1979, Damals im alten Österreich, Benedikt has set apart a large and important segment-more than one hundred pages - for the history of his family; there are marvelous vignettes of people like Edmund Benedikt, his father's brother, a distinguished liberal lawyer and politician, or Karl Emil Franzos, the writer, his father's brother-in-law. The father, Rudolf Benedikt, was professor of chemistry at Vienna's Technische Hochschule.

Rarely has a historian's life been as much at variance with the usual canon of academic progress as Benedikt's. He began his academic career as a docent in 1947, at the age of sixty-one, and he became a professor in 1950, at the age of sixty-four! Benedikt's first doctorate was in law (1911), and for decades, interrupted by military service in World War 1 (including service with the Armeeoberkommando in Teschen), he was active in the management of business enterprises, particularly in sugar production, spending many years in the Bohemian lands. He approached history as an amateur, gifted in the art of imaginative correlation, knowledgeable in many languages, from Czech to Italian and Spanish; he was meticulous in research. The first product of his love affair with history was the large volume on Franz Anton Graf von Sporck 1662-1738, published in 1923. The baroque age was to remain his favorite epoch. His second great book Das Königreich Neapel unter Kaiser Karl VI, came out in 1927; three years later it was accepted in lieu of a dissertation by Professors Srbik and Pribram, and Benedikt, at the age of forty-four, got his Ph.D. in history. Those who tend to stress the element of easy story telling, even of anecdotes, in Benedikt's writings, are advised to read the account of an autodafé in Palermo; in that book (pp. 246-258), amidst the detailed description of the baroque splendor of the ceremonies, the author's pity for the two victims and his contempt for the abominable barbarity of the proceedings stand out. It makes powerful, unforgettable reading. 
Nazism forced Benedikt to emigrate to England (his beloved sister Alice perished in the holocaust), where he made a modest living in selling secondhand books. After the Second World War it was at the suggestion and invitation of Hugo Hantsch that Benedikt, in his seventh decade, became an academic teacher. Benedikt's productivity in his sixties and seventies is astounding. Of his numerous books from that period, only a few shall be mentioned: Die Friedensaktion der Meinl-Gruppe 1917/18 (1962), with interesting source material; and his books on the "Austrian period" in Italian and Belgian history (Kaiseradler über dem Appenin (1964), and Als Belgien österreichisch war (1965).

Benedikt enchanted those who knew him by his charm, his wit, and his serenity. Yet, in his writings, his extraordinary knowledge of biographical, cultural, and economic events and developments and their mutual interdependence lies open, presented without portentousness in a crystal-clear style.

In 1947 Benedikt published his book-length essay, Monarchie der Gegensätze (an enlarged revision in 1968 is entitled Die Monarchie des Hauses Österreich). There he revealed what for him meant the essence of that monarchy whose splendor he had felt more strongly than the tremor announcing the final crisis. The formula of coincidentia oppositorum, which he found in the work of Nikolaus Cusanus, the bishop of Brixen, in the fifteenth century, became for Benedikt the idée force of the Habsburg monarchy: "The attempt to maintain opposites instead of suppressing them, the attempt to preserve them in all their colorfulness created by God and to join them in a more exalted unity of peace" - that experiment now was a matter of the past. For those who knew Benedikt and for those who look at his work, Benedikt will be remembered as the last historian of the Habsburg empire who also had been its living witness.'

University of Vienna

Gerald STOURZH

'A bibliography of Benedikt's writings, compiled by Ferdinand Schmied, can be found in the Festschrift published on the occasion of his eightieth birthday: Bausteine zur Geschichte Österreichs. In Archiv für österreichische Geschichte, Vol. CXXV (1966). The reader should also see Günther Hamann, "Heinrich Benedikt (30. Dezember 1886-26. Dezember 1981) zum Gedenken," in Wiener Beiträge zur Geschichte der Neuzeit, Vol. IX (1982), pp. 9-2I. 